\title{
Steam Reforming of Ethanol over CoMg/SBA-15 Catalysts
}

\author{
Josh Y. Z. Chiou ${ }^{1}$, Shih-Yi Yang ${ }^{1}$, Chin-Liang Lai ${ }^{1}$, Hsuan-Ying Kung ${ }^{1}$, \\ Chih-Wei Tang ${ }^{2}$, Chen-Bin Wang ${ }^{{ }^{*}}$ \\ ${ }^{1}$ Department of Chemical and Materials Engineering, Chung Cheng Institute of Technology, \\ National Defense University, Taoyuan, Chinese Taipei \\ ${ }^{2}$ Department of General Education, Army Academy, Taoyuan, Chinese Taipei \\ Email: "chenbinwang@gmail.com
}

Received March 19, 2013; revised April 20, 2013; accepted May 17, 2013

Copyright (C) 2013 Josh Y. Z. Chiou et al. This is an open access article distributed under the Creative Commons Attribution License, which permits unrestricted use, distribution, and reproduction in any medium, provided the original work is properly cited.

\begin{abstract}
Hydrogen production through steam reforming of ethanol (SRE) over Mg modified Co-based catalysts supported on mesoporous SBA-15 was studied herein to evaluate the catalytic activity and the behavior of coke deposition. The $\mathrm{Co}_{\mathrm{y}} \mathrm{Mg}_{\mathrm{x}} / \mathrm{SBA}-15$ catalysts are obtained according to the steps of consecutive impregnation of $\mathrm{Mg}(\mathrm{x}=5 \mathrm{and} 10 \mathrm{wt} \%)$ to be incorporated on SBA-15 and then follow the loading of Co (y = 10 and $20 \mathrm{wt} \%)$ using the incipient wetness impregnation method. The catalysts are characterized by using X-ray diffraction (XRD), temperature programmed reduction (TPR), transmission electron microscopy (TEM) and BET techniques. Also, the spent catalysts are further characterized by using XRD and TEM. The catalytic activity of the SRE is evaluated in a fixed-bed reactor under $22,000 \mathrm{~h}^{-1}$ GHSV and with an $\mathrm{H}_{2} \mathrm{O} / \mathrm{EtOH}$ molar ratio of 13 . All the $\mathrm{Co}_{\mathrm{y}} \mathrm{Mg}_{\mathrm{x}} / \mathrm{SBA}-15$ catalysts present a mesoporous structure, even after the SRE reaction. The optimum catalyst of $\mathrm{Co}_{20} \mathrm{Mg}_{5} / \mathrm{SBA}-15-\mathrm{H} 650$ comes from the high loading of Co and high reduction temperature pretreatment, which show a high catalytic activity and stability at $550^{\circ} \mathrm{C}$ with a hydrogen yield $\left(\mathrm{Y}_{\mathrm{H} 2}\right)$ up to 5.78 and $\mathrm{CO}$ selectivity around $3.10 \%$.
\end{abstract}

Keywords: SBA-15; Steam Reforming of Ethanol; Cobalt; Magnesium

\section{Introduction}

Hydrogen generation from biomass-derived alcohols has been the activity of choice recently. Ethanol is more attractive because it is non-toxic, has higher hydrogen content, is renewable energy and has an easy-to-handle nature when compared to methanol [1,2]. The main catalytic reaction using ethanol to produce hydrogen by steam reforming is shown in Equation (1), where only hydrogen and non-renewable $\mathrm{CO}_{2}$ are produced, providing 6 moles of $\mathrm{H}_{2}$ per mole of ethanol stoichiometrically [3].

$$
\mathrm{C}_{2} \mathrm{H}_{5} \mathrm{OH}+3 \mathrm{H}_{2} \mathrm{O} \rightarrow 6 \mathrm{H}_{2}+2 \mathrm{CO}_{2}
$$

Several metallic active phases have been used as catalysts for the steam reforming of ethanol (SRE) to produce hydrogen. Since Co-based catalysts, mainly metal exhibiting appreciable activity for C-C bond broken and water-gas shift (WGS) reactions, generate a low temperature and few by-products, they are efficient when used in SRE. The early stage of SRE research has focused on Co-based catalysts. Haga et al. [4] found that the proper-

\footnotetext{
${ }^{*}$ Corresponding author.
}

ties of cobalt catalysts were greatly influenced by the supports, where the hydrogen production decreased in the order of: $\mathrm{Co} / \mathrm{Al}_{2} \mathrm{O}_{3}>\mathrm{Co} / \mathrm{ZrO}_{2}>\mathrm{Co} / \mathrm{MgO}>\mathrm{Co} / \mathrm{SiO}_{2}$ $>\mathrm{Co} / \mathrm{C}$. The $\mathrm{Co} / \mathrm{Al}_{2} \mathrm{O}_{3}$ catalyst showed high hydrogen selectivity for SRE by suppressing $\mathrm{CO}$ methanation and ethanol decomposition. Supported cobalt catalysts showed a significant improvement in catalytic performance on the SRE compared with corresponding supports reported by Llorca et al. [5], a variety of oxides involving acidic/ basic and redox properties. Batista et al. [6] studied the high efficiency SRE over $\mathrm{Co} / \mathrm{Al}_{2} \mathrm{O}_{3}$ and $\mathrm{Co} / \mathrm{SiO}_{2}$ catalysts with little $\mathrm{Co}$ content $(8 \%)$ in which the $\mathrm{Co} / \mathrm{SiO}_{2}$ catalyst showed better $\mathrm{CO}$ removal. Llorca et al. [7] reported CO-free hydrogen produced from SRE over the $\mathrm{Co} / \mathrm{ZnO}$ catalyst at low temperatures, where the highly stable catalyst was prepared by using $\mathrm{Co}_{2}(\mathrm{CO})_{8}$ as a precursor.

The technique of doping extra components, such as alkali ( $\mathrm{Li}, \mathrm{Na}$ and $\mathrm{K}$ ) [8], alkaline earth $(\mathrm{Mg}$ and $\mathrm{Ca}$ ) [9, 10] and lanthanide (La and $\mathrm{Ce}$ ) [10] to modify the originnal property and improve the performance of a catalyst is interesting. Pigos et al. [8] reported that the addition of $\mathrm{Na}$ and $\mathrm{K}$ significantly improved the formate decomposi- 
tion rate on a WGS reaction over $\mathrm{Pt} / \mathrm{ZrO}_{2}$ catalysts. Wang et al. [9] reported that the addition of $\mathrm{Na}$ improved the catalytic performance of a $\mathrm{PtRu} / \mathrm{ZrO}_{2}$ catalyst on the oxidative steam reforming of ethanol, where the $\mathrm{Na}$ not only enhanced the WGS reaction at a low temperature, but also reduced coke deposition. Cheng et al. [10] also reported the promotional effect of doping alkaline earth oxides or lanthanide oxides on a $\mathrm{Ni} / \mathrm{Al}_{2} \mathrm{O}_{3}$ catalyst for $\mathrm{CO}_{2}$ reforming of $\mathrm{CH}_{4}$.

Besides the selection of an active metal or promoter for the supported catalysts, the choice of a support with a high surface area to disperse the metal phase over their surface is a main consideration to enhance catalytic performance. Support material, such as $\gamma-\mathrm{Al}_{2} \mathrm{O}_{3}, \mathrm{SiO}_{2}, \mathrm{ZSM}-5$ [11], MCM-41 [12] and SBA-15 [13], have been widely used in recent years as catalyst supports for catalytic reactions occurring at high temperatures, based on the support material's larger pores, thicker walls and higher thermal stability. Of considerable interest in this regard are mesoporous materials as a support that will provide an improvement on hydrogen production via steam reforming reaction [14-19]. The promoter effect of alkaline earth metals ( $\mathrm{Mg}$ and $\mathrm{Ca}$ ) over $\mathrm{Cu}-\mathrm{Ni} / \mathrm{SBA}-15$ [16] and $\mathrm{Cu}-\mathrm{Ni} / \mathrm{SiO}_{2}$ [18] catalysts has been studied; both of them improved the dispersion of the metallic phase and strengthened the metal-support interaction. High hydrogen selectivity was obtained with $\mathrm{Mg}$ and reduced deposited carbon with the incorporation of $\mathrm{Ca}$. A promoter made up of a $\mathrm{Ce}_{\mathrm{x}} \mathrm{Zr}_{1-\mathrm{x}} \mathrm{O}_{2}$ layer pre-coated on SBA-15 changes the redox properties and enhances the catalytic activity on steam reforming of methane over a Ni-based catalyst, as reported by Wang et al. [19].

It is well known that Co-based catalysts suffer from deactivation by carbon deposition at high reaction temperatures [20]. This is obviously an important point to consider in SRE reactions related to Co-based catalysts. The SBA-15 supported Co catalysts with high surface area and modified by an $\mathrm{Mg}$ promoter were prepared in this work. The catalytic performance and coking behavior of hydrogen production via SRE over mesoporous structure catalysts were also considered.

\section{Experimental}

\subsection{Catalyst Preparation}

SBA-15 was prepared according to the method described in the literature [13]. Briefly, a triblock copolymer P123 (8 g, Strem) was dissolved in $250 \mathrm{~mL} \mathrm{HCl}(1.9 \mathrm{M})$. The solution was stirred at $40^{\circ} \mathrm{C}$ for $2 \mathrm{~h}$, and $16 \mathrm{~g}$ of tetraethyl orthosilicate (TEOS) were then slowly added to the mixture and stirred vigorously at $40^{\circ} \mathrm{C}$ for $22 \mathrm{~h}$. The solution was transferred into a Teflon bottle and aged at $100^{\circ} \mathrm{C}$ for $24 \mathrm{~h}$. The solid product was filtered, washed with deionized water and then dried at room temperature for 24 $\mathrm{h}$, followed by calcination in air at $500^{\circ} \mathrm{C}$ for $6 \mathrm{~h}$ with a heating rate of $7^{\circ} \mathrm{C} / \mathrm{min}$.

Catalysts promoted with alkaline are much more sensitive to the preparation order for catalytic performance, and the promoting effect is more significant when the support is impregnated with the promoter oxides before the incorporation of the active phase [10]. For this reason, Mg-modified Co/SBA-15 catalysts are prepared by consecutive impregnation with $\mathrm{Mg}$ and then $\mathrm{Co} . \mathrm{Mg}_{\mathrm{x}} / \mathrm{SBA}-$ 15 samples were prepared from the aqueous solution of $\mathrm{Mg}\left(\mathrm{NO}_{3}\right)_{2} \cdot 6 \mathrm{H}_{2} \mathrm{O}$ (Mg loading, $\mathrm{x}=5$ and $10 \mathrm{wt} \%$, Showa) incorporating SBA-15 by the impregnation method. $\mathrm{Co}_{\mathrm{y}} \mathrm{Mg}_{\mathrm{x}} / \mathrm{SBA}-15$ samples were prepared by the incipient wetness impregnation method using $\mathrm{Mg}_{\mathrm{x}} / \mathrm{SBA}-15$ with aqueous $\mathrm{Co}\left(\mathrm{NO}_{3}\right)_{2} \cdot 6 \mathrm{H}_{2} \mathrm{O}$ (Co loading, $\mathrm{y}=10$ and 20 $\mathrm{wt} \%$, Showa). All samples were dried at $100^{\circ} \mathrm{C}$ overnight and then calcined at $300^{\circ} \mathrm{C}$ for $3 \mathrm{~h}$.

\subsection{Catalyst Characterization}

The metal loading of catalysts was determined by the atomic-emission technique (ICP-AES) using a Perkin Elmer Optima 3000 DV. The BET surface area and pore size distribution were measured by $\mathrm{N}_{2}$ adsorption at a liquid nitrogen temperature using a Micromeritics ASAP 2010 analyzer. X-ray diffraction (XRD) measurement was performed using a Siemens D5000 diffractometer with $\mathrm{Cu}$ $\mathrm{K}_{\alpha 1}$ radiation $(\lambda=1.5406 \AA)$ at $40 \mathrm{kV}$ and $30 \mathrm{~mA}$. The microstructure and particle size of the samples were observed by using transmission electron microscopy (TEM) with a JEOL JEM-2010 microscope equipped with a field emission electron source and operated at $200 \mathrm{kV}$. Reduction behavior of $\mathrm{Co}_{\mathrm{y}} \mathrm{Mg}_{\mathrm{x}} / \mathrm{SBA}-15$ catalysts was studied by temperature-programmed reduction (TPR). About $50 \mathrm{mg}$ of the sample were heated in a flow of $10 \% \mathrm{H}_{2} / \mathrm{N}_{2}$ gas at a flow rate of $10 \mathrm{ml} \cdot \mathrm{min}^{-1}$. During TPR, the temperature was increased by $7^{\circ} \mathrm{C} \cdot \mathrm{min}^{-1}$ from room temperature to $900^{\circ} \mathrm{C}$.

\subsection{Activity Tests}

Catalytic activity of $\mathrm{Co}_{\mathrm{y}} \mathrm{Mg}_{\mathrm{x}} / \mathrm{SBA}-15$ catalysts in an SRE reaction was determined at atmospheric pressure in a fixed-bed flow reactor. $100 \mathrm{mg}$ of the catalyst were placed in a $4 \mathrm{~mm}$ i.d. quartz tubular reactor and held by glass-wool plugs. The temperature of the reactor was controlled by heating tape and measured by a thermocouple (1.2 mm i.d.) at the center of the reactor bed. The feed of the reactants was comprised of a gaseous mixture of ethanol (EtOH), $\mathrm{H}_{2} \mathrm{O}$ and $\mathrm{Ar}$ (purity 99.9995\%, supplied by a mass flow controller). The composition of the reactant mixture $\left(\mathrm{H}_{2} \mathrm{O} / \mathrm{EtOH} / \mathrm{Ar}=37 / 3 / 60\right.$ vol\%) was controlled by the Ar flow stream $(22 \mathrm{~mL} / \mathrm{min})$ through a saturator (maintained at $120^{\circ} \mathrm{C}$ ) containing $\mathrm{EtOH}$ and $\mathrm{H}_{2} \mathrm{O}$. The gas hourly space velocity (GHSV) was main- 
tained at 22,000 $\mathrm{h}^{-1}$ and the $\mathrm{H}_{2} \mathrm{O} / \mathrm{EtOH}$ molar ratio was $13\left(\mathrm{H}_{2} \mathrm{O}: \mathrm{EtOH}=80: 20\right.$ by volume $)$. Prior to reactivity measurement, the catalyst was reduced in $10 \% \mathrm{H}_{2}$ in $\mathrm{N}_{2}$ for $2 \mathrm{~h}$ at $400^{\circ} \mathrm{C}$. The SRE activity was tested stepwise, increasing the temperature from $350^{\circ} \mathrm{C}$ to $550^{\circ} \mathrm{C}$. The reaction was carried out online by gas chromatography (GC) with columns of Porapak Q (for $\mathrm{CO}_{2}, \mathrm{H}_{2} \mathrm{O}, \mathrm{C}_{2} \mathrm{H}_{4}$, $\mathrm{CH}_{3} \mathrm{CHO}, \mathrm{CH}_{3} \mathrm{OCH}_{3}$ and $\mathrm{EtOH}$ ) and using a Molecular Sieve $5 \AA$ (for $\mathrm{H}_{2}, \mathrm{CH}_{4}$ and $\mathrm{CO}$ ) for separation. It was also quantitatively analyzed by two sets of thermal conductivity detectors (TCD) on line. Response factors for all products were obtained, and the system was calibrated with appropriate standards before each catalytic test. Activity evaluation of all samples depended on the conversion of ethanol $\left(\mathrm{X}_{\mathrm{EtOH}}\right)$, the distribution of products (mol $\%)$ and the yield of hydrogen $\left(\mathrm{Y}_{\mathrm{H} 2}, \mathrm{~mol} \mathrm{H}_{2} / \mathrm{mol} \mathrm{EtOH}\right)$ according to the following equations.

$$
\begin{array}{r}
\mathrm{X}_{\mathrm{EtOH}}=\left(n_{\mathrm{EtOH}, \text { reacted }} / n_{\mathrm{EtOH}, \text { fed }}\right) \times 100 \% \\
\mathrm{Y}_{\mathrm{H} 2}=n_{\mathrm{H} 2-\text { out }} / n_{\mathrm{EtOH}, \text { reacted }} \\
\mathrm{S}_{\mathrm{i}}=\left(n_{\mathrm{i}} / \sum n_{\mathrm{i}}\right) \times 100 \%
\end{array}
$$

where $n_{\mathrm{i}}$ was a mole of products and included $\mathrm{H}_{2}$.

\section{Results and Discussion}

\subsection{Characterization of Supports and Catalysts}

The XRD patterns at small angles of SBA-15, $\mathrm{Mg}_{\mathrm{x}} /$ SBA-15 and $\mathrm{Co}_{\mathrm{y}} \mathrm{Mg}_{\mathrm{x}} / \mathrm{SBA}-15(\mathrm{x}=5$ and $10 ; \mathrm{y}=10$ and 20) samples are shown in Figure 1. The SBA-15 support (Figure 1(a)) shows a pattern with three well-resolved peaks observed at $2 \theta$ values of $0.92^{\circ}, 1.54^{\circ}$ and $1.77^{\circ}$ that correspond to the diffraction of (100), (110) and (200) planes, respectively, indicating their ordered $2 \mathrm{D}$ hexagonal structure with space group $p 6 \mathrm{~mm}$ [13]. The $d$-spacing of this structure, calculated from $\mathrm{n} \lambda=2 d \sin \theta$ is $9.6 \mathrm{~nm}$, which is also in the mesoporous range. Both $\mathrm{Mg}_{\mathrm{x}} /$ SBA-15 samples ( $x=5$ and 10) are presented in Figures 1(b) and (c), respectively. The intensity of the diffraction peaks of the hexagonal mesostructure decreases gradually with the increase of $x$ from 5 to 10 . Moreover, a similar trend can be observed with the decrease in $d$-spacing where the $d$-spacing for $\mathrm{x}=5$ and 10 are 9.3 and $9.0 \mathrm{~nm}$, respectively. The intensity of diffraction peaks for the $\mathrm{Co}_{\mathrm{y}} \mathrm{Mg}_{\mathrm{x}} / \mathrm{SBA}-15$ ( $\mathrm{y}=10$ and 20 ) catalysts (Figures 1(d)-(h)) decreases with the increase of $x$ and $y$, and weakens more than the $\mathrm{Mg}_{\mathrm{x}} / \mathrm{SBA}-15$ samples. Furthermore, the material composed of a high surface area, larger pores and thicker walls seems to disintegrate with increasing metal loading, raising doubt about the structural integrity.

The $\mathrm{N}_{2}$ adsorption-desorption analysis of the $\mathrm{Co}_{\mathrm{y}} \mathrm{Mg}_{\mathrm{x}} /$ SBA-15 catalysts is shown in Figure 2. All of the samples exhibit a Type IV isotherm with a clear H1-type

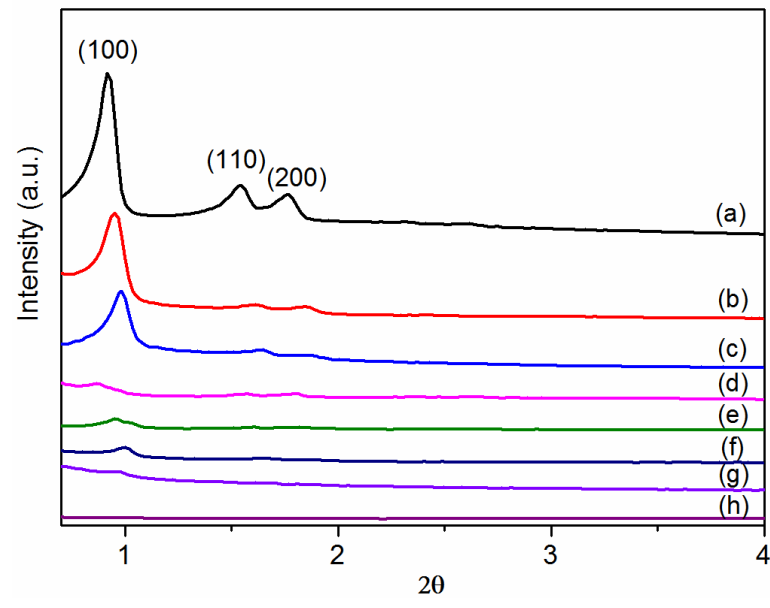

Figure 1. Small angle XRD patterns of the samples: (a) SBA-15 (b) $\mathrm{Mg}_{5} / \mathrm{SBA}-15$ (c) $\mathrm{Mg}_{10} / \mathrm{SBA}-15$ (d) $\mathrm{Co}_{10} \mathrm{Mg}_{5} /$ SBA-15 (e) $\mathrm{Co}_{20} \mathrm{Mg}_{5} / \mathrm{SBA}-15$ (f) $\mathrm{Co}_{20} \mathrm{Mg}_{5} / \mathrm{SBA}-15-\mathrm{H} 650$ (g) $\mathrm{Co}_{10} \mathrm{Mg}_{10} / \mathrm{SBA}-15$ (h) $\mathrm{Co}_{20} \mathrm{Mg}_{10} / \mathrm{SBA}-15$.

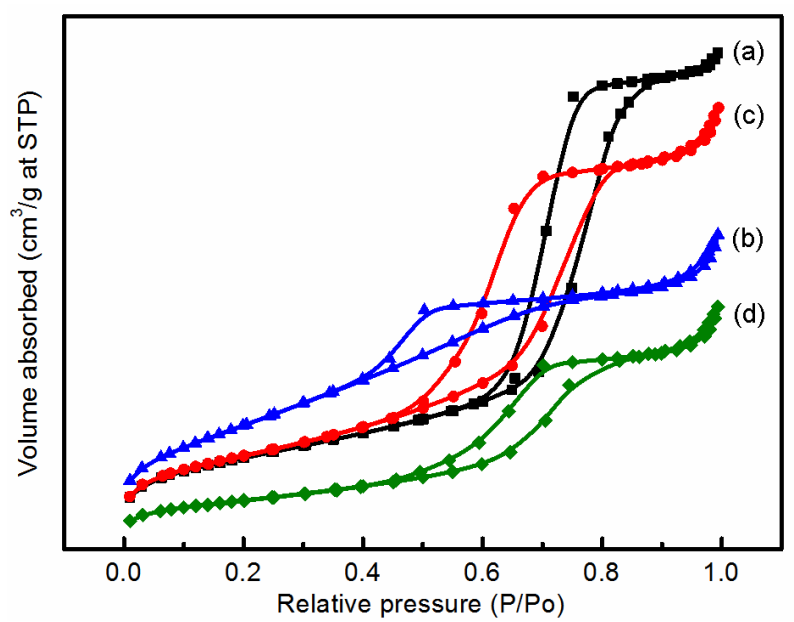

Figure 2. $\mathrm{N}_{2}$ adsorption/desorption isotherms of the samples: (a) $\mathrm{Co}_{10} \mathrm{Mg}_{5} / \mathrm{SBA}-15$ (b) $\mathrm{Co}_{10} \mathrm{Mg}_{10} / \mathrm{SBA}-15$ (c) $\mathrm{Co}_{20} \mathrm{Mg}_{5} /$ SBA-15 (d) $\mathrm{Co}_{20} \mathrm{Mg}_{10} / \mathrm{SBA}-15$.

hysteresis loop, with metal loading or not (SBA-15 and $\mathrm{Mg}_{\mathrm{x}} / \mathrm{SBA}-15$ samples are not shown), which is typical for mesoporous materials. Even though the XRD analysis showed the destruction of the hexagonal structure with impregnation of cobalt, the SBA-15 supported catalysts still maintained the mesoporous structure. Table 1 summarizes the physical characterization of $\mathrm{Co}_{\mathrm{y}} \mathrm{Mg}_{\mathrm{x}} / \mathrm{SBA}-15$ catalysts, which includes the metal loading, surface area and phase composition. The surface area decreases with the increase of the $(x+y)$ value, where the surface areas are $359,313,234$ and $130 \mathrm{~m}^{2} / \mathrm{g}$, respectively for the values of 15, 20, 25 and 30. The decrease of surface area indicates that the mesoporous structure may be blocked by large amounts of $\mathrm{Mg}$ and Co loading.

The wide-angle XRD patterns of the $\mathrm{Co}_{\mathrm{y}} \mathrm{Mg}_{\mathrm{x}} / \mathrm{SBA}-15$ catalysts are shown in Figure 3 . The broad and wide 
Table 1. Physical characterization of the $\mathrm{Co}_{\mathrm{y}} \mathrm{Mg}_{\mathrm{x}} / \mathrm{SBA}-15$ catalysts.

\begin{tabular}{|c|c|c|c|c|c|}
\hline \multirow{2}{*}{ Catalyst } & \multicolumn{2}{|c|}{ Metal loading (wt \%) ${ }^{\mathrm{a}}$} & \multirow{2}{*}{$\mathrm{Co} / \mathrm{Mg}$ ratio $(\%)$} & \multirow{2}{*}{$\begin{array}{l}\text { Surface areab } \\
\qquad\left(\mathrm{m}^{2} / \mathrm{g}\right)\end{array}$} & \multirow{2}{*}{ Phase $^{c}$} \\
\hline & Co & $\mathrm{Mg}$ & & & \\
\hline $\mathrm{Co}_{10} \mathrm{Mg}_{5} / \mathrm{SBA}-15$ & 8.68 & 4.18 & 67 & 359 & $\mathrm{Co}_{3} \mathrm{O}_{4},(\mathrm{Co}, \mathrm{Mg}) \mathrm{O}$ \\
\hline $\mathrm{Co}_{10} \mathrm{Mg}_{10} / \mathrm{SBA}-15$ & 9.12 & 8.24 & 50 & 313 & $\mathrm{Co}_{3} \mathrm{O}_{4},(\mathrm{Co}, \mathrm{Mg}) \mathrm{O}$ \\
\hline $\mathrm{Co}_{20} \mathrm{Mg}_{10} / \mathrm{SBA}-15$ & 19.0 & 8.16 & 67 & 130 & $\mathrm{Co}_{3} \mathrm{O}_{4}, \mathrm{MgCo}_{2} \mathrm{O}_{4},(\mathrm{Co}, \mathrm{Mg}) \mathrm{O}$ \\
\hline $\mathrm{Co}_{20} \mathrm{Mg}_{5} / \mathrm{SBA}-15$ & 18.4 & 4.81 & 80 & 234 & $\mathrm{Co}_{3} \mathrm{O}_{4}, \mathrm{MgCo}_{2} \mathrm{O}_{4},(\mathrm{Co}, \mathrm{Mg}) \mathrm{O}$ \\
\hline $\mathrm{Co}_{20} \mathrm{Mg}_{5} / \mathrm{SBA}-15-\mathrm{H} 650$ & 18.4 & 4.81 & 80 & 220 & $\mathrm{MgCo}_{2}$ \\
\hline
\end{tabular}

${ }^{a}$ ICP-AES measurement. ${ }^{b}$ BET measurement. ${ }^{\mathrm{c}}$ The phase was identified by the XRD and TPR analysis.

peak at $2 \theta$ around $15^{\circ}-30^{\circ}$ is characteristic of amorphous silica. The peak related to $\mathrm{MgO}\left(2 \theta \approx 42^{\circ}\right)$ is unobservable in the XRD patterns for $\mathrm{Co}_{\mathrm{y}} \mathrm{Mg}_{\mathrm{x}} / \mathrm{SBA}-15$ catalysts, which indicate the Mg shows highly dispersed on SBA-15 or becomes the nickel-magnesia solid solution oxides $(\mathrm{Co}, \mathrm{Mg}) \mathrm{O}[21,22]$. Both the Co10Mg5/ SBA-15 and Co10Mg10/SBA-15 catalysts (Figure 3(a) and (b)) show the characteristic diffraction peaks corresponding to the (220), (311), (511) and (440) planes at $31.3^{\circ}, 36.8^{\circ}, 59.0^{\circ}$ and $64.8^{\circ}$, respectively. These are related to the cubic phase of $\mathrm{Co}_{3} \mathrm{O}_{4}$ (JCPDS No: 76-1802). The spinel structure of magnesium cobaltite $\mathrm{MgCo}_{2} \mathrm{O}_{4}$ $[23,24]$ (JCPDS No: 81-0671) shows the corresponding planes of (111), (220), (311), (400), (511) and (440) at $18.9^{\circ}, 31.1^{\circ}, 36.6^{\circ}, 44.5^{\circ}, 58.9^{\circ}$ and $64.7^{\circ}$, respectively. These are obtained on the high Co loading catalysts of Co20Mg5/SBA-15 and Co20Mg10/SBA-15 (Figures 3(c) and (d)). Otherwise, the higher Co loading would show the stronger diffraction signal. In here, both the $\mathrm{Co}_{3} \mathrm{O}_{4}$ and $\mathrm{MgCo}_{2} \mathrm{O}_{4}$ phases are not able to give clear assignment, because their diffraction peaks are overlapped. Choudhary et al. [25] reported that the $\mathrm{MgCo}_{2} \mathrm{O}_{4}$ phase was only observed in the case of catalysts with high Co loadings, such as over $20 \%$, which was supported by our results when $\mathrm{y}=20$. Therefore, the $\mathrm{Co}_{\mathrm{y}} \mathrm{Mg}_{\mathrm{x}} / \mathrm{SBA}-15$ catalysts may contain two phases of $\mathrm{Co}_{3} \mathrm{O}_{4}$ and $\mathrm{MgCo}_{2} \mathrm{O}_{4}$, and further investigation will be discussed on TPR analysis.

Figure 4 shows the TPR profiles of the $\mathrm{Co}_{\mathrm{y}} \mathrm{Mg}_{\mathrm{x}} / \mathrm{SBA}$ 15 catalysts. There are two continuous reduction peaks around $180^{\circ} \mathrm{C}$ to $350^{\circ} \mathrm{C}$ and broad peak around $500^{\circ} \mathrm{C}$ to $700^{\circ} \mathrm{C}$, respectively. While the lower temperature peaks may be related to the two-steps reduction of $\mathrm{Co}_{3} \mathrm{O}_{4}$ [26] and the higher temperature peak is assigned the reduction of $\mathrm{MgCo}_{2} \mathrm{O}_{4}$ [25]. Besides, a faint peak over $800^{\circ} \mathrm{C}$ may be attributed to the reduction of cobalt-magnesia solid solution oxides $(\mathrm{Co}, \mathrm{Mg}) \mathrm{O}$ formed on the catalysts [27]. Further, the reduction signal of $\mathrm{Co}_{3} \mathrm{O}_{4}$ would be raised by increasing the Co loading. These results are confirmed to the XRD study, the $\mathrm{Co}_{3} \mathrm{O}_{4}$ and $\mathrm{MgCo}_{2} \mathrm{O}_{4}$ phases are coexisting in $\mathrm{Co}_{\mathrm{y}} \mathrm{Mg}_{\mathrm{x}} / \mathrm{SBA}-15$ catalysts. Particularly, the

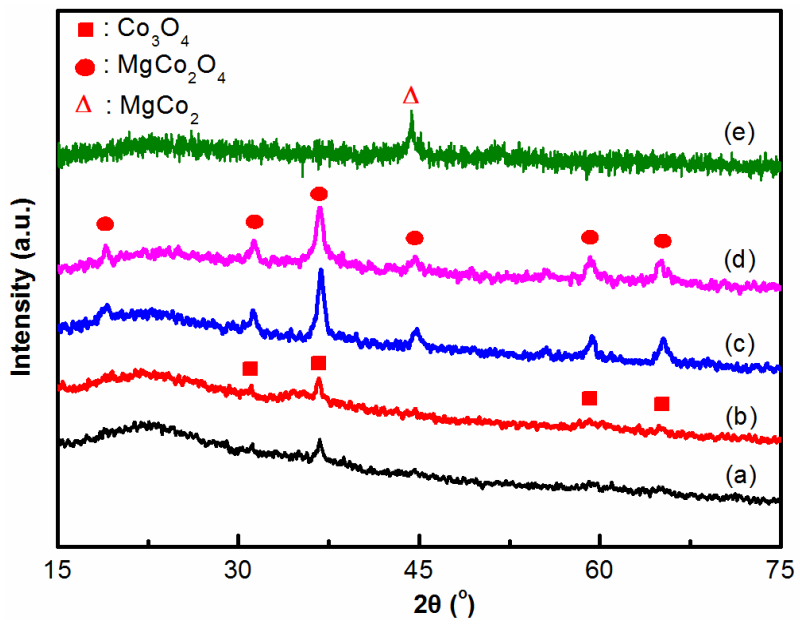

Figure 3. Wide angle XRD patterns of the samples: (a) $\mathrm{Co}_{10} \mathrm{Mg}_{5} / \mathrm{SBA}-15$ (b) $\mathrm{Co}_{10} \mathrm{Mg}_{10} / \mathrm{SBA}-15$ (c) $\mathrm{Co}_{20} \mathrm{Mg}_{5} / \mathrm{SBA}-15$ (d) $\mathrm{Co}_{20} \mathrm{Mg}_{10} / \mathrm{SBA}-15$ (e) $\mathrm{Co}_{20} \mathrm{Mg}_{5} / \mathrm{SBA}-15-\mathrm{H} 650$.

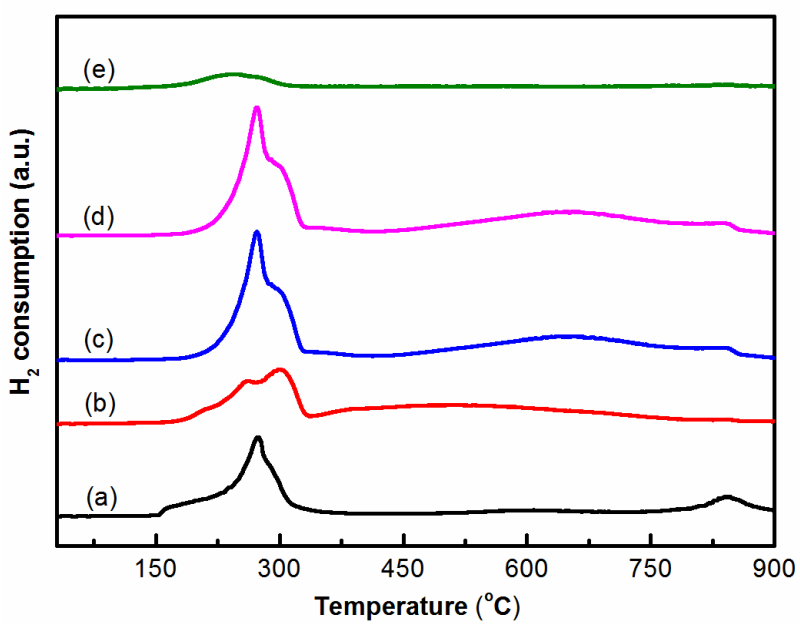

Figure 4. TPR profiles of the samples: (a) $\mathrm{Co}_{10} \mathrm{Mg}_{5} / \mathrm{SBA}-15$ (b) $\mathrm{Co}_{10} \mathrm{Mg}_{10} / \mathrm{SBA}-15$ (c) $\mathrm{Co}_{20} \mathrm{Mg}_{5} / \mathrm{SBA}-15$ (d) $\mathrm{Co}_{20} \mathrm{Mg}_{10} /$ SBA-15 (e) $\mathrm{Co}_{20} \mathrm{Mg}_{5} / \mathrm{SBA}-15-\mathrm{H} 650$.

lower $\mathrm{Mg}$ loading will product the less amount of $\mathrm{MgCo}_{2} \mathrm{O}_{4}$ phase. 


\subsection{Catalytic Performance}

Catalytic performance of ethanol conversion $\left(\mathrm{X}_{\mathrm{EtOH}}\right)$, products distribution and hydrogen yield $\left(\mathrm{Y}_{\mathrm{H} 2}\right)$ for the $\mathrm{Co}_{\mathrm{y}} \mathrm{Mg}_{\mathrm{x}} / \mathrm{SBA}-15$ catalysts are summarized in Table 2. The $\mathrm{X}_{\mathrm{EtOH}}$ reaches completion for $\mathrm{Co}_{10} \mathrm{Mg}_{5} / \mathrm{SBA}-15$,
$\mathrm{Co}_{10} \mathrm{Mg}_{10} / \mathrm{SBA}-15$ and $\mathrm{Co}_{20} \mathrm{Mg}_{10} / \mathrm{SBA}-15$ catalysts as the reaction temperature $\left(\mathrm{T}_{\mathrm{R}}\right)$ approaches $475^{\circ} \mathrm{C}$; while the $\mathrm{Y}_{\mathrm{H} 2}$ only approaches less than 2.0 at $550^{\circ} \mathrm{C}$. Otherwise, both the $\mathrm{Co}_{20} \mathrm{Mg}_{5} / \mathrm{SBA}-15 \mathrm{Co}_{20} \mathrm{Mg}_{5} / \mathrm{SBA}-15-\mathrm{H} 650$ catalysts show that the $\mathrm{Y}_{\mathrm{H} 2}$ increases with $\mathrm{T}_{\mathrm{R}}$ and up to 5.02 and 5.78 , respectively at $550^{\circ} \mathrm{C}$.

Table 2. Products distribution of SRE reaction over $\mathrm{Co}_{\mathrm{y}} \mathrm{Mg}_{\mathrm{x}} / \mathrm{SBA}-15$ catalysts.

\begin{tabular}{|c|c|c|c|c|c|c|c|c|c|}
\hline \multirow{2}{*}{ Catalyst } & \multirow{2}{*}{$\mathrm{T}_{\mathrm{R}}\left({ }^{\circ} \mathrm{C}\right)$} & \multirow{2}{*}{$\mathrm{X}_{\mathrm{EtOH}}(\%)$} & \multicolumn{6}{|c|}{ Products distribution $(\%)^{\mathrm{a}}$} & \multirow{2}{*}{$\mathrm{Y}_{\mathrm{H} 2}$} \\
\hline & & & $\mathrm{H}_{2}$ & $\mathrm{CH}_{4}$ & $\mathrm{CO}$ & $\mathrm{CO}_{2}$ & $\mathrm{C}_{2} \mathrm{H}_{4}$ & $\mathrm{C}_{2} \mathrm{H}_{4} \mathrm{O}$ & \\
\hline \multirow{8}{*}{$\mathrm{Co}_{10} \mathrm{Mg}_{5} / \mathrm{SBA}-15$} & 400 & 44.4 & 44.2 & 0 & 0 & 0 & 16.7 & 38.4 & 0.73 \\
\hline & 425 & 52.6 & 44.9 & 0.14 & 0 & 0 & 17.2 & 38.6 & 0.76 \\
\hline & 450 & 90.0 & 45.6 & 0.42 & 0.03 & 0 & 17.5 & 38.5 & 0.79 \\
\hline & 500 & 100 & 46.4 & 1.75 & 1.15 & 1.24 & 9.29 & 40.2 & 0.90 \\
\hline & 525 & 100 & 54.2 & 8.73 & 4.73 & 4.72 & 7.41 & 20.2 & 1.48 \\
\hline & 550 & 100 & 52.6 & 11.3 & 6.38 & 4.68 & 6.07 & 18.9 & 1.46 \\
\hline & 400 & 57.3 & 39.6 & 0.08 & 0 & 0 & 19.7 & 40.6 & 0.66 \\
\hline & 425 & 76.2 & 40.6 & 0.22 & 0 & 0 & 20.2 & 39.1 & 0.68 \\
\hline \multirow[t]{7}{*}{$\mathrm{Co}_{10} \mathrm{Mg}_{10} / \mathrm{SBA}-15$} & 475 & 100 & 44.5 & 1.23 & 0.62 & 1.56 & 18.6 & 33.6 & 0.83 \\
\hline & 500 & 100 & 48.1 & 3.28 & 2.02 & 3.24 & 14.5 & 28.9 & 1.01 \\
\hline & 525 & 100 & 50.4 & 6.81 & 3.54 & 4.75 & 11.2 & 23.3 & 1.20 \\
\hline & 550 & 100 & 51.4 & 13.2 & 6.38 & 7.13 & 8.39 & 13.5 & 1.46 \\
\hline & 400 & 41.5 & 44.6 & 0 & 0 & 0 & 11.7 & 43.7 & 1.18 \\
\hline & 425 & 72.6 & 41.9 & 0.15 & 0 & 0 & 17.4 & 40.5 & 1.18 \\
\hline & 450 & 83.8 & 41.5 & 0.29 & 0 & 0.44 & 20.0 & 37.8 & 1.33 \\
\hline \multirow[t]{5}{*}{$\mathrm{Co}_{20} \mathrm{Mg}_{10} / \mathrm{SBA}-15$} & 475 & 100 & 46.9 & 0.64 & 0.26 & 1.22 & 24.5 & 26.5 & 1.48 \\
\hline & 500 & 100 & 49.2 & 1.76 & 1.40 & 2.12 & 22.1 & 23.5 & 1.73 \\
\hline & 525 & 100 & 49.7 & 2.05 & 1.84 & 2.21 & 21.3 & 23.0 & 1.70 \\
\hline & 425 & 51.5 & 40.7 & 0.44 & 1.46 & 0 & 12.4 & 45.1 & 0.70 \\
\hline & 450 & 100 & 47.0 & 1.81 & 6.16 & 0 & 12.5 & 32.5 & 0.96 \\
\hline \multirow[t]{7}{*}{$\mathrm{Co}_{20} \mathrm{Mg}_{5} / \mathrm{SBA}-15$} & 475 & 100 & 60.3 & 5.43 & 11.1 & 8.54 & 9.41 & 5.15 & 2.22 \\
\hline & 500 & 100 & 70.0 & 4.21 & 8.00 & 16.7 & 1.17 & 0 & 4.48 \\
\hline & 525 & 100 & 71.4 & 4.49 & 3.54 & 20.6 & 0 & 0 & 4.99 \\
\hline & 550 & 100 & 71.5 & 4.07 & 3.88 & 20.5 & 0 & 0 & 5.02 \\
\hline & 400 & 32.9 & 52.0 & 0.06 & 0.47 & 5.37 & 0 & 42.1 & 1.15 \\
\hline & 425 & 100 & 62.7 & 6.68 & 16.9 & 2.25 & 0 & 11.5 & 2.97 \\
\hline & 450 & 100 & 74.4 & 6.98 & 1.48 & 17.2 & 0 & 0 & 5.56 \\
\hline \multirow[t]{4}{*}{$\mathrm{Co}_{20} \mathrm{Mg}_{5} / \mathrm{SBA}-15-\mathrm{H} 650$} & 475 & 100 & 74.4 & 4.79 & 1.80 & 19.0 & 0 & 0 & 5.60 \\
\hline & 500 & 100 & 74.2 & 3.43 & 2.38 & 19.8 & 0 & 0 & 5.76 \\
\hline & 525 & 100 & 74.3 & 3.20 & 3.05 & 19.5 & 0 & 0 & 5.78 \\
\hline & 550 & 100 & 74.3 & 3.15 & 3.10 & 19.6 & 0 & 0 & 5.78 \\
\hline
\end{tabular}

${ }^{a}$ Water is not included. 
Based on the phase diagram of the Mg-Co system [28], there is an equilibrium phase for $\mathrm{MgCo}_{2}$ when Co loading is over $67 \%$. Two conditions are required to obtain $\mathrm{MgCo}_{2} \mathrm{O}_{4}$ : a high Co loading over $20 \mathrm{wt} \%$ [25] and a $\mathrm{Co} / \mathrm{Mg}$ ratio over $67 \%$ [28]. In regard to the pretreatment with reduction temperature effects for the sample with a $\mathrm{Co} / \mathrm{Mg}$ ratio over $67 \%$, a $\varepsilon$ Co structure is the major type for a reduction temperature below $422^{\circ} \mathrm{C}$. Otherwise, an $\alpha \mathrm{Co}$ structure shows for a reduction temperature over $422^{\circ} \mathrm{C}$ [28]. Compared to the pretreatment of temperature effects, a $\mathrm{Co}_{20} \mathrm{Mg}_{5} / \mathrm{SBA}-15$ catalyst is reduced by $\mathrm{H}_{2}$ at $650^{\circ} \mathrm{C}$ for $2 \mathrm{~h}$ (denoted as $\mathrm{Co}_{20} \mathrm{Mg}_{5} / \mathrm{SBA}-15-\mathrm{H} 650$ ). The $\mathrm{XRD}$ characterization is shown in Figure 3(e) and the TPR analysis is shown in Figure 4(e). The XRD of $\mathrm{Co}_{20} \mathrm{Mg}_{5} / \mathrm{SBA}-15-\mathrm{H} 650$ catalyst presences only a diffraction peak around $45^{\circ} \mathrm{C}$ that can be identified and assigned to the (400) plane of the $\mathrm{MgCo}_{2}$ phase (JCPDS No. 29-0486). Since the $\mathrm{Co}_{20} \mathrm{Mg}_{5} / \mathrm{SBA}-15-\mathrm{H} 650$ sample is storage in atmosphere, the oxidation of sample may be occurred. A TPR profile of $\mathrm{Co}_{20} \mathrm{Mg}_{5} / \mathrm{SBA}-15-\mathrm{H} 650$ shows a weak peak below $350^{\circ} \mathrm{C}$ which relates to the reduction of $\mathrm{Co}_{3} \mathrm{O}_{4}$.

In order to understand the variation in the $\mathrm{Co} / \mathrm{Mg}$ ratio over $67 \%$ and pretreatment with the reduction temperature effect, both the $\mathrm{Co}_{20} \mathrm{Mg}_{5} / \mathrm{SBA}-15$ and $\mathrm{Co}_{20} \mathrm{Mg}_{5} /$ SBA-15-H650 samples are further discussed. Temperature profiles of catalytic performance on the SRE reaction over the $\mathrm{Co}_{20} \mathrm{Mg}_{5} / \mathrm{SBA}-15$ and $\mathrm{Co}_{20} \mathrm{Mg}_{5} / \mathrm{SBA}-15-$ H650 samples are described in Figures 5 and 6. There are significant differences in catalytic activity and products distribution due to the high temperature reduction. The $\mathrm{Co}_{20} \mathrm{Mg}_{5} / \mathrm{SBA}-15-\mathrm{H} 650$ sample is better than the $\mathrm{Co}_{20} \mathrm{Mg}_{5} / \mathrm{SBA}-15$ sample. The results indicate that the $\mathrm{X}_{\mathrm{EtOH}}$ approaches completion around $425^{\circ} \mathrm{C}$ for $\mathrm{Co}_{20} \mathrm{Mg}_{5} /$ SBA-15-H650 samples while requiring $450^{\circ} \mathrm{C}$ for $\mathrm{Co}_{20}$ $\mathrm{Mg}_{5} / \mathrm{SBA}-15$ samples to complete the conversion. The $\mathrm{Y}_{\mathrm{H} 2}$ increases up to 5.78 and $\mathrm{S}_{\mathrm{CO}}$ is $3.10 \%$ for the $\mathrm{Co}_{20}$ $\mathrm{Mg}_{5} / \mathrm{SBA}-15-\mathrm{H} 650$ sample, while the $\mathrm{Y}_{\mathrm{H} 2}$ approaches 5.02 and $\mathrm{S}_{\mathrm{CO}}$ is $3.88 \%$ for the $\mathrm{Co}_{20} \mathrm{Mg}_{5} / \mathrm{SBA}-15$ sample at $550^{\circ} \mathrm{C}$. Dehydration especially from ethanol to ethylene is a dominant reaction for all samples that are not pretreated under high temperature reduction, where the selectivity of $\mathrm{C}_{2} \mathrm{H}_{4}$ is over $10 \%$.

$$
\mathrm{C}_{2} \mathrm{H}_{5} \mathrm{OH} \rightarrow \mathrm{C}_{2} \mathrm{H}_{4}+\mathrm{H}_{2} \mathrm{O}
$$

The main reaction is the dehydrogenation of ethanol to acetaldehyde at low temperature. As the temperature raised, a major reaction proceeded the decomposition of acetaldehyde into methane and $\mathrm{CO}$ for $\mathrm{Co}_{20} \mathrm{Mg}_{5} / \mathrm{SBA}-15$ and $\mathrm{Co}_{20} \mathrm{Mg}_{5} / \mathrm{SBA}-15-\mathrm{H} 650$ samples.

$$
\begin{aligned}
& \mathrm{C}_{2} \mathrm{H}_{5} \mathrm{OH} \rightarrow \mathrm{CH}_{3} \mathrm{CHO}+\mathrm{H}_{2} \\
& \mathrm{CH}_{3} \mathrm{CHO} \rightarrow \mathrm{CH}_{4}+\mathrm{CO}
\end{aligned}
$$

Comparing the temperature effect on the decomposi-

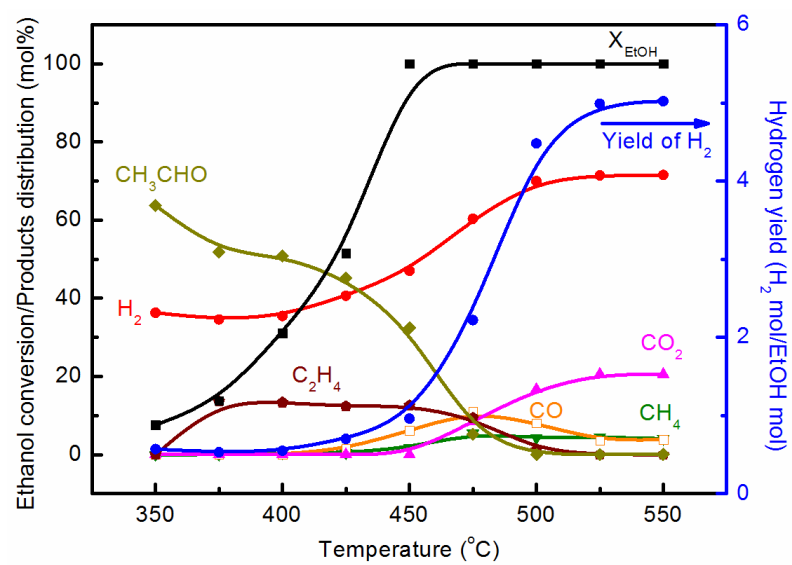

Figure 5. Catalytic performance of SRE reaction over $\mathrm{Co}_{20} \mathrm{Mg}_{5} / \mathrm{SBA}-15$ catalyst.

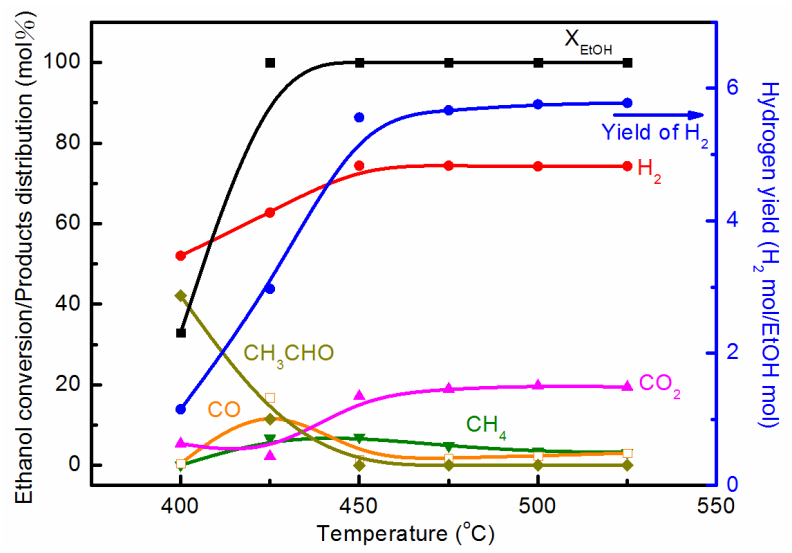

Figure 6. Catalytic performance of SRE reaction over $\mathrm{Co}_{20} \mathrm{Mg}_{5} / \mathrm{SBA}-15-\mathrm{H} 650$ catalyst.

tion of acetaldehyde $\left(\mathrm{D}_{\mathrm{T}}\right)$, shows that the easy cracking of acetaldehyde promotes the increase of hydrogen yield. However, the promoting effect of a $\mathrm{Co}_{20} \mathrm{Mg}_{5} / \mathrm{SBA}-15-$ $\mathrm{H} 650$ sample is more pronounced than that of $\mathrm{C} \mathrm{Co}_{20} \mathrm{Mg}_{5} /$ SBA-15 sample. The $\mathrm{D}_{\mathrm{T}}$ of a $\mathrm{Co}_{20} \mathrm{Mg}_{5} / \mathrm{SBA}-15-\mathrm{H} 650$ sample is lower than $400^{\circ} \mathrm{C}$, while it is above $450^{\circ} \mathrm{C}$ for a $\mathrm{Co}_{20} \mathrm{Mg}_{5} / \mathrm{SBA}-15$ sample.

The distribution of $\mathrm{CO}$ is minor when the $\mathrm{T}_{\mathrm{R}}$ is above $425^{\circ} \mathrm{C}$ for $\mathrm{a} \mathrm{Co}_{20} \mathrm{Mg}_{5} / \mathrm{SBA}-15-\mathrm{H} 650$ sample. This demonstates that the water-gas shift reaction (WGSR) is an important side-reaction in the SRE reaction producing $\mathrm{H}_{2}$ and $\mathrm{CO}_{2}$.

$$
\mathrm{CO}+\mathrm{H}_{2} \mathrm{O} \rightarrow \mathrm{CO}_{2}+\mathrm{H}_{2}
$$

At $525^{\circ} \mathrm{C}$, the selectivity of $\mathrm{CH}_{4}, \mathrm{CO}$ and $\mathrm{CO}_{2}$ arrive at

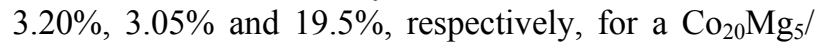
SBA-15-H650 sample. The hydrogen selectivity is close to its stoichiometric value $(75 \%)$, whereas an increase of up to $74 \%$ is obtained at over $450^{\circ} \mathrm{C}$. Unlike the $\mathrm{Co}_{20} \mathrm{Mg}_{5} / \mathrm{SBA}-15$ and $\mathrm{Co}_{20} \mathrm{Mg}_{5} / \mathrm{SBA}-15-\mathrm{H} 650$ samples, other $\mathrm{Co}_{\mathrm{y}} \mathrm{Mg}_{\mathrm{x}} / \mathrm{SBA}-15$ catalysts show poor catalytic performance in an SRE reaction. The low $\mathrm{H}_{2}$ yields $(<1.9)$ 
and $\mathrm{CO}_{2}$ selectivity are produced by the ethanol dehydration to ethylene followed by steam reforming, where $\mathrm{C}_{2} \mathrm{H}_{4}$ is up to $20 \%$ at $450^{\circ} \mathrm{C}$. However, the formation of carbon through $\mathrm{C}_{2} \mathrm{H}_{4}$ is a possible route, which leads to catalyst deactivation.

$$
\mathrm{C}_{2} \mathrm{H}_{4} \rightarrow \text { polymer } \rightarrow \text { coke }
$$

\subsection{Characterization of Used Catalyst}

XRD and TEM analysis are used to characterize the $\mathrm{Co}_{\mathrm{y}} \mathrm{Mg}_{\mathrm{x}} / \mathrm{SBA}-15$ catalysts after the SRE reaction. XRD patterns reveal $\mathrm{MgO}$ (JCDPS No. 4-829) and $\mathrm{CoO}$ (JCDPS No. 78-0431) diffraction patterns on $\mathrm{Co}_{10} \mathrm{Mg}_{5} /$ SBA-15, $\mathrm{Co}_{10} \mathrm{Mg}_{10} / \mathrm{SBA}-15$ and $\mathrm{Co}_{20} \mathrm{Mg}_{10} / \mathrm{SBA}-15$ samples (Figures 7(a), (b) and (e)). Only the $\mathrm{Co}_{20} \mathrm{Mg}_{5} /$ SBA-15 and $\mathrm{Co}_{20} \mathrm{Mg}_{5} / \mathrm{SBA}-15-\mathrm{H} 650$ samples show metallic Co (JCDPS No. 89-4307) reflections of (111) and (200) planes (Figures 7(c) and (d)). These results are in good agreement, helping to convince researchers that the $\mathrm{Co}_{20} \mathrm{Mg}_{5} / \mathrm{SBA}-15$ and $\mathrm{Co}_{20} \mathrm{Mg}_{5} / \mathrm{SBA}-15-\mathrm{H} 650$ samples show the better catalytic activity than others in an SRE reaction, exhibiting an active site of metallic Co. The metallic Co usually generated via the reduction of $\mathrm{Co}_{3} \mathrm{O}_{4}$, which was easily sintered if the interaction with the support was absent [27]. However, the $\mathrm{Co}_{20} \mathrm{Mg}_{5} / \mathrm{SBA}-15$ and $\mathrm{Co}_{20} \mathrm{Mg}_{5} / \mathrm{SBA}-15-\mathrm{H} 650$ samples could form $\mathrm{MgCo}_{2} \mathrm{O}_{4}$ or $\mathrm{MgCo}_{2}$ phases and formatted well-dispersed Co clusters, which are more resistant to sintering due to a stronger interaction between $\mathrm{MgO}$ and the support [25]. Based on previous reports [27,29], coke formation would not be stimulated on well-dispersed Co clusters to deactivate the catalyst.

The TEM images (Figure 8) show that carbon deposited as large filaments and tubes emerged with the catalyst particles and/or as an amorphous coating carbon on

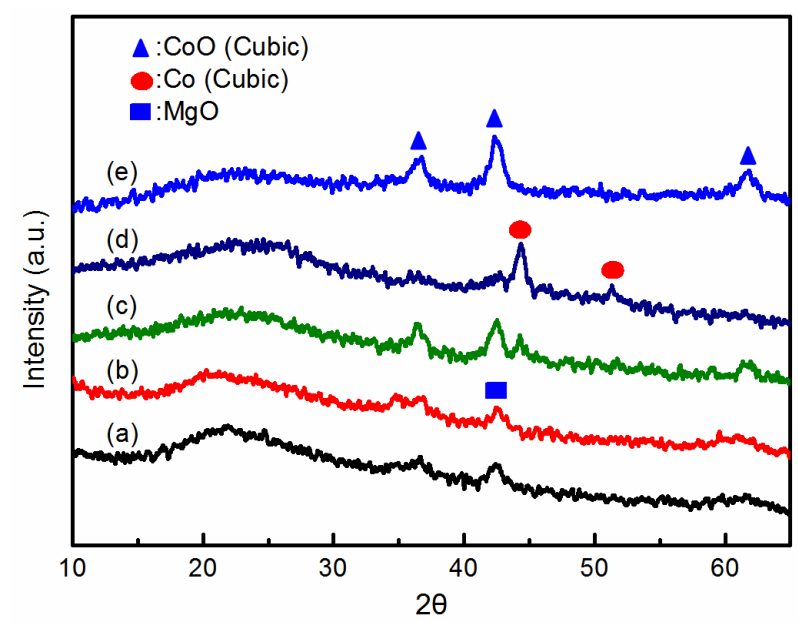

Figure 7. Wide angle XRD patterns of spent catalysts: (a) $\mathrm{Co}_{10} \mathrm{Mg}_{5} / \mathrm{SBA}-15$ (b) $\mathrm{Co}_{10} \mathrm{Mg}_{10} / \mathrm{SBA}-15$ (c) $\mathrm{Co}_{20} \mathrm{Mg}_{5} / \mathrm{SBA}-15$ (d) $\mathrm{Co}_{20} \mathrm{Mg}_{5} / \mathrm{SBA}-15-\mathrm{H} 650$ (e) $\mathrm{Co}_{20} \mathrm{Mg}_{10} / \mathrm{SBA}-15$.

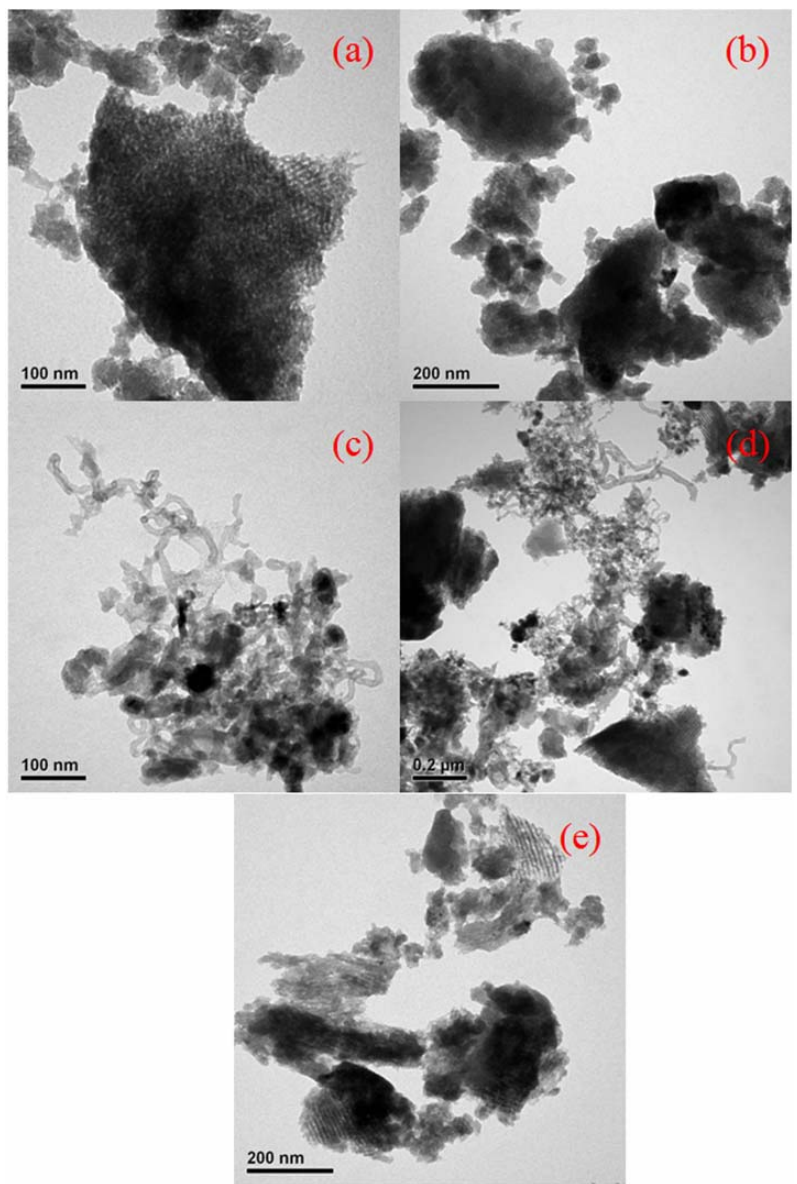

Figure 8. TEM images of spent catalysts: (a) $\mathrm{Co}_{10} \mathrm{Mg}_{5} /$ SBA-15 (b) $\mathrm{Co}_{10} \mathrm{Mg}_{10} / \mathrm{SBA}-15$ (c) $\mathrm{Co}_{20} \mathrm{Mg}_{5} / \mathrm{SBA}-15$ (d) $\mathrm{Co}_{20} \mathrm{Mg}_{5} / \mathrm{SBA}-15-\mathrm{H} 650$ (e) $\mathrm{Co}_{20} \mathrm{Mg}_{10} / \mathrm{SBA}-15$.

the catalyst particles. The filaments and tubes carbon is shown in the $\mathrm{Co}_{20} \mathrm{Mg}_{5} / \mathrm{SBA}-15$ and $\mathrm{Co}_{20} \mathrm{Mg}_{5} / \mathrm{SBA}-15-$ H650 samples (Figures 8(c) and (d)), and amorphous carbon is presented in the $\mathrm{Co}_{10} \mathrm{Mg}_{5} / \mathrm{SBA}-15, \mathrm{Co}_{10} \mathrm{Mg}_{10} /$ SBA-15 and $\mathrm{Co}_{20} \mathrm{Mg}_{10} / \mathrm{SBA}-15$ catalysts (Figures 8(a), (b) and (e)). According to the deactivation with the deposited carbon, the coating carbon could shorten the lifetime of a catalyst rather than filaments carbon [30], which agreed with our results. Moreover, all the samples maintain a mesoporous structure of SBA-15 after the SRE reaction. A good thermal stability is presented.

\section{Conclusion}

Steam reforming of ethanol was studied over SBA-15 supported catalysts with a $\mathrm{Mg}$ promoter and a cobalt loading of 10 and $20 \mathrm{wt} \%$. The $\mathrm{Co} / \mathrm{Mg}$ ratio and pretreatment of catalysts play a major role on the catalytic performance regarding the structural properties. A high catalytic performance and hydrogen yield were obtained on the high loading of $\mathrm{Co}$, where the $\mathrm{Co} / \mathrm{Mg}$ ratio was 0.8. According to the phase diagram of an Mg-Co system, 
a reduction temperature of $650^{\circ} \mathrm{C}$ would form $\mathrm{MgCo}_{2}$ as the main phase convinced by $\mathrm{XRD}$, which leads to the active site to enhance the catalytic performance. The $\mathrm{Y}_{\mathrm{H} 2}$ approaches 5.78 and the $\mathrm{S}_{\mathrm{CO}}$ is $3.10 \%$ for $\mathrm{Co}_{20} \mathrm{Mg}_{5} / \mathrm{SBA}-$ 15-H650 sample as the $\mathrm{T}_{\mathrm{R}}$ approaches $550^{\circ} \mathrm{C}$.

\section{Acknowledgements}

We are pleased to acknowledge the financial support for this study by the National Science Council of the Republic of China under contract numbers of NSC 99-2113M-606-001-MY3 and NSC 101-2623-E-155- 001-ET.

\section{REFERENCES}

[1] R. D. Cortright, R. R. Davda and J. A. Dumesic, "Hydrogen from Catalytic Reforming of Biomass-Derived Hydrocarbons in Liquid Water," Nature, Vol. 418, No. 6901, 2002, pp. 964-967. doi:10.1038/nature01009

[2] D. K. Liguras, D. I. Kondarides and X. E. Verykios, "Production of Hydrogen For Fuel Cells by Steam Reforming of Ethanol over Supported Noble Metal Catalysts," Applied Catalysis B: Environmental, Vol. 43, No. 4, 2003, pp. 345-354. doi:10.1016/S0926-3373(02)00327-2

[3] P. Ramirez de la Piscina and N. Homs, "Use of Biofuels to Produce Hydrogen (Reformation Processes)," Chemical Society Review, Vol. 37, No. 11, 2008, pp. 2459-2467. doi:10.1039/b712181b

[4] F. Haga, T. Nakajima, H. Miya and S. Mishima, "Catalytic Properties of Supported Cobalt Catalysts for Steam Reforming of Ethanol," Catalysis Letters, Vol. 48, No. 34, 1997, pp. 223-227. doi:10.1023/A:1019039407126

[5] J. Llorca, N. Homs, J. Sales and P. Ramirez de la Piscina, "Efficient Production of Hydrogen over Supported Cobalt Catalysts from Ethanol Steam Reforming," Journal of Catalysis, Vol. 209, No. 2, 2002, pp. 306-317. doi:10.1006/jcat.2002.3643

[6] M. C. Batista, R. K. S. Santos, E. M. Assaf, J. M. Assaf and E. A. Ticianelli, "High Efficiency Steam Reforming of Ethanol by Cobalt-Based Catalysts," Journal of Power Sources, Vol. 134, No. 1, 2004, pp. 27-32. doi:10.1016/i.jpowsour.2004.01.052

[7] J. Llorca, P. Ramirez de la Piscina, J.-A. Dalmon, J. Sales and N. Homs, "CO-Free Hydrogen from Steam-Reforming of Bioethanol over ZnO-Supported Cobalt Catalysts Effect of the Metallic Precursor," Applied Catalysis B: Environmental, Vol. 43, No. 4, 2003, pp. 355-369. doi:10.1016/S0926-3373(02)00326-0

[8] J. M. Pigos, C. J. Brooks, G. Jacobs and B. H. Davis, "Low Temperature Water-gas Shift: The Effect of Alkali Doping on the $\mathrm{C}-\mathrm{H}$ Bond of Formate over $\mathrm{Pt} / \mathrm{ZrO}_{2}$ Catalysts," Applied Catalysis A: General, Vol. 328, No. 1, 2007, pp. 14-26. doi:10.1016/j.apcata.2007.04.001

[9] C. H. Wang, K. F. Ho, J. Y. Z. Chiou, C. L. Lee, S. Y. Yang, C. T. Yeh and C. B. Wang, "Oxidative Steam Reforming of Ethanol over PtRu/ZrO $\mathrm{Zr}_{2}$ Catalysts Modified with Sodium and Magnesium," Catalysis Communica- tions, Vol. 12, No. 10, 2011, pp. 854-858. doi:10.1016/j.catcom.2011.02.002

[10] Z. Cheng, Q. Wu, J. Li and Q. Zhu, "Effects of Promoters and Preparation Procedures on Reforming of Methane with Carbon Dioxide over $\mathrm{Ni} / \mathrm{Al}_{2} \mathrm{O}_{3}$ Catalyst," Catalalysis Today, Vol. 30, No. 1-3, 1996, pp. 147-155. doi:10.1016/0920-5861(95)00005-4

[11] D. H. Olson, G. T. Kokotailo, S. L. Lawton and W. M. Meler, "Crystal Structure and Structure-Related Properties of ZSM-5," The Journal of Physical Chemistry, Vol. 85, No. 15, 1981, pp. 2238-2243. doi: $10.1021 / \mathrm{j} 150615 \mathrm{a} 020$

[12] C. T. Kresge, M. E. Leonowicz, W. J. Roth, J. C. Vartuli and J. S. Beck, "Ordered Mesoporous Molecular Sieves Synthesized by a Liquid-crystal Template Mechanism," Nature, Vol. 359, No. 6397, 1992, pp. 710-712. doi: $10.1038 / 359710 \mathrm{a} 0$

[13] D. Zhao, J. Feng, Q. Huo, N. Melosh, G. H. Fredrickson, B. F. Chmelka and G. D. Stucky, "Triblock Copolymer Syntheses of Mesoporous Silica with Periodic 50 to 300 Angstrom Pores," Science, Vol. 279, No. 5350, 1998, pp. 548-552. doi:10.1126/science. 279.5350 .548

[14] A. J. Vizcaíno, A. Carrero and J. A. Calles, "Hydrogen Production by Ethanol Steam Reforming over $\mathrm{Cu}-\mathrm{Ni}$ Supported Catalysts" International Journal of Hydrogen Energy, Vol. 32, No. 10-11, 2007, pp. 1450-1461. doi:10.1016/j.ijhydene.2006.10.024

[15] A. Carrero, J. A. Calles and A. J. Vizcaíno, "Hydrogen Production by Ethanol Steam Reforming over $\mathrm{Cu}-\mathrm{Ni}$ / SBA-15 Supported Catalysts Prepared by Direct Synthesis and Impregnation," Applied Catalysis A: General, Vol. 327, No. 1, 2007, pp. 82-94. doi:10.1016/j.apcata.2007.04.030

[16] A. J. Vizcaíno, A. Carrero and J. A. Calles, "Ethanol Steam Reforming on Mg- and Ca-modified Cu-Ni/SBA-15 Catalysts," Catalysis Today, Vol. 146, No. 1-2, 2009, pp. 6370. doi:10.1016/j.cattod.2008.11.020

[17] J. A. Calles, A. Carrero and A. J. Vizcaíno, "Ce and La Modification of Mesoporous Cu-Ni/SBA-15 Catalysts for Hydrogen Production through Ethanol Steam Reforming," Microporous and Mesoporous Materials, Vol. 119, No. 1-3, 2009, pp. 200-207. doi:10.1016/j.micromeso.2008.10.028

[18] A. Carrero, J. A. Calles and A. J. Vizcaino, "Effect of Mg and $\mathrm{Ca}$ Addition on Coke Deposition over $\mathrm{Cu}-\mathrm{Ni} / \mathrm{SiO}_{2}$ Catalysts for Ethanol Steam Reforming," Chemical Engineering Journal, Vol. 163, No. 3, 2010, pp. 395-402. doi:10.1016/j.cej.2010.07.029

[19] K. Wang, X. Li, S. Ji, X. Shi and J. Tang, "Effect of $\mathrm{Ce}_{\mathrm{x}} \mathrm{Zr}_{1-\mathrm{x}} \mathrm{O}_{2}$ Promoter on Ni-Based SBA-15 Catalyst for Steam Reforming of Methane," Energy \& Fuels, Vol. 23, No. 1, 2009, pp. 25-31. doi:10.1021/ef800553b

[20] H. Wang, Y. Liu, L. Wang and Y. Qin, "Study on the Carbon Deposition in Steam Reforming of Ethanol over $\mathrm{Co} / \mathrm{CeO}_{2}$ Catalyst," Chemical Engineering Journal, Vol. 145, No. 1, 2008, pp. 25-31. doi:10.1016/j.cej.2008.02.021

[21] B. Huang, X. Li, S. Ji, B. Lang, F. Habimana and C. Li, "Effect of MgO Promoter on Ni-based SBA-15 Catalysts 
for Combined Steam and Carbon Dioxide Reforming of Methane," Journal of Natural Gas Chemistry, Vol. 17, No. 3, 2008, pp. 225-231. doi:10.1016/S1003-9953(08)60055-9

[22] W. Liu, S. Y. Lai, H. X. Dai, S. J. Wang, H. Z. Sun and C. T. Au, "MgO-Modified $\mathrm{VO}_{\mathrm{x}} / \mathrm{SBA}-15$ as Catalysts for the Oxidative Dehydrogenation of $n$-Butane," Catalysis Today, Vol. 131, No. 1-4, 2008, pp. 450-456. doi:10.1016/j.cattod.2007.10.054

[23] M. A. Zamudio, S. Bensaid, D. Fino and N. Russo, "Influence of the $\mathrm{MgCo}_{2} \mathrm{O}_{4}$ Preparation Method on $\mathrm{N}_{2} \mathrm{O}$ Catalytic Decompositio," Industrial \& Engineering Chemistry Research, Vol. 50, No. 5, 2011, pp. 2622-2627. doi:10.1021/ie100658w

[24] Y. Sharma, N. Sharma, G. V. Subba Rao and B. V. R. Chowdari, "Studies on Spinel Cobaltites, $\mathrm{FeCo}_{2} \mathrm{O}_{4}$ and $\mathrm{MgCo}_{2} \mathrm{O}_{4}$ as Anodes for Li-ion batteries," Solid State Ionics, Vol. 179, No. 15-16, 2008, pp. 587-597. doi:10.1016/j.ssi.2008.04.007

[25] V. R. Choudhary, K. C. Mondal and T. V. Choudhary, " $\mathrm{CO}_{2}$ Reforming of Methane to Syngas over $\mathrm{CoO}_{\mathrm{x}} / \mathrm{MgO}$ Supported on Low Surface Area Macroporous Catalyst Carrier: Influence of Co Loading and Process Conditions," Industrial \& Engineering Chemistry Research, Vol. 45, No. 13, 2006, pp. 4597-4602. doi:10.1021/ie060260a
[26] C. B. Wang, C. C. Lee, J. L. Bi, J. Siang, J. Y. Liu and C. T. Yeh, "Study on the Steam Reforming of Ethanol over Cobalt Oxides," Catalysis Today, Vol. 146, No. 1-2, 2009, pp. 76-81. doi:10.1016/j.cattod.2008.12.010

[27] H. Y. Wang and E. Ruckenstein, " $\mathrm{CO}_{2}$ Reforming of $\mathrm{CH}_{4}$ over $\mathrm{Co} / \mathrm{MgO}$ Solid Solution Catalysts-Effect of Calcination Temperature and Co loading," Applied Catalysis A: General, Vol. 209, No. 1-2, 2001, pp. 207-215. doi:10.1016/S0926-860X(00)00753-5

[28] A. A. Nayeb-Hashemi and J. B. Clark, "The Co-Mg (Cobalt-Magnesium) System," Bulletin of Alloy Phase Diagrams, Vol. 8, No. 4, 1987, pp. 352-354.

[29] E. Ruckenstein and H. Y. Wang, "Carbon Deposition and Catalytic Deactivation during $\mathrm{CO}_{2}$ Reforming of $\mathrm{CH}_{4}$ over $\mathrm{Co} / \gamma-\mathrm{Al}_{2} \mathrm{O}_{3}$ Catalysts," Journal of Catalysis, Vol. 205, No. 2, 2002, pp. 289-293. doi:10.1006/jcat.2001.3458

[30] I. Suelves, M. J. Lázaro, R. Moliner, B. M. Corbella and J. M. Palacios, "Hydrogen Production by Thermo Catalytic Decomposition of Methane on Ni-Based Catalysts: Influence of Operating Conditions on Catalyst Deactivation and Carbon Characteristics," International Journal of Hydrogen Energy, Vol. 30, No. 15, 2005, pp. 1555-1567. doi:10.1016/j.ijhydene.2004.10.006 